\title{
4. Research degrees in journalism: What is an exegesis?
}

\section{ABSSTRACI}

This article addresses the question of what might constitute an exegesis for a higher degree by research in journalism, and briefly canvasses issues for journalism as a disciplinary research practice. It starts by considering the craft/profession/discipline dichotomies to clarify the sort of journalism that might qualify as research, typically but not necessarily long form and/ or investigative. It identifies the three core elements of the exegesis as a literature review, an exposition of the methodology and an evaluation of the success of the journalism component of the project in answering the research question. It notes that all journalism, like history and other humanities disciplines, is necessarily interdisciplinary, and therefore the journalistic methodology should interface with that of the cognate discipline. It argues that the singularity and value of journalism as a research practice lie in its combination of a reflexive empirical focus, a focus on contemporary phenomena and an intense engagement with the politics of knowledge. It suggests that meta-theoretical debates about reflexivity, space, time and fields are strongly applicable to methodological debates in journalism.

Keywords: exegesis, investigative journalism, journalism, journalism history, literature review, reflexivity, research, research methodologies, theses

\section{CHRIS NASH}

Monash University, Melbourne

\begin{abstract}
$\Delta$ S JOURNALISM programmes in universities expand from coursework to include research projects, theses and dissertations at hofocus: what is the relationship between journalistic research and traditional scholarly research? For research degree candidates and their supervisors the pointy end of this question manifests in the guise of the exegesis: what is it, and what do I have to do to produce one? I am concerned here with
\end{abstract}


journalism, but would argue that the principles apply mutatis mutandis to all 'non-traditional' modes of rigorous knowledge production that might be required to reconcile themselves to the modalities of 'traditional' research and scholarship. What constitutes traditional disciplinarity itself is a dynamic historical phenomenon (Messer-Davidow et al., 1993; Turner, 2012) and as such embroiled in contests that the binary polarity of traditional versus non-traditional tends to obfuscate. Nonetheless, these are the terms in which degree requirements are currently framed, and we have to start the discussion somewhere.

There is a debate, at times engaged and invigorating but more often cursory and disparaging, about whether journalism as such can ever be a form of rigorous research practice at the level of scholarship (see Nash, 2013, for a consideration of this issue in the context of research assessment exercises in Australia). This issue requires extended engagement elsewhere (inter alia Nash, 2015, forthcoming), but the Australian Research Council (ARC) recognises Journalism as a research activity under Field of Research (FoR) Code 1903 (Turner, 2011, p. 5), and hence a number of universities including my own both offer research degrees in journalism and also report on the research achievements of academic researchers in FoR1903 through the Excellence in Research for Australia (ERA) process, managed by the ARC. Any journalism that is proposed for ERA recognition as academic research has to be accompanied by a 250-word statement of its merits as such, and a sample of submitted work is examined by disciplinary experts to confirm its quality. The definition of research that applies in the Australian context is

Research is defined as the creation of new knowledge and/or the use of existing knowledge in a new and creative way so as to generate new concepts, methodologies and understandings. This could include synthesis and analysis of previous research to the extent that it leads to new and creative outcomes. (Australian Research Council, 2008, p. 1)

The United Kingdom and New Zealand definitions are comparable (Bacon, 2011, p. 50), and most interestingly, the definitions of investigative journalism used by the European Journalism Fund include that of the Dutch-Flemish Association for Investigative Journalism which is journalism that is "critical and thorough [which] can be done by creating new facts but also through re-interpretation or correlation of facts already at hand' (quoted in Bacon, 
2011, p. 48) - a definition that resonates remarkably with the academic definitions of research (see Pacific Journalism Review 17 (1), 2011, for a exploration of the practice of investigative journalism in the university context).

Journalism researches and reports to a public on the contemporary and material state of affairs in any given situation. Stuart Adam put it thus:

If journalism is marked by its public voice, it is marked equally by its relation to the here and now. Michael Oakeshott, a British philosopher, once defined 'the world of history [as] the real world as a whole comprehended under the category of the past'. The world of journalism, by contrast, may be the real world as a whole comprehended under the category of the present ....[J]ournalism is avowedly about the present, not the past. So the preliminary definition of journalism contains a least these four elements: reporting, judging, a public voice, and the here and now. (Adam, 1994, p. 13 [my emphasis])

It is worth noting that although Adam himself is engaging with a craft definition of journalism, the parallel with history implies equivalent status as a discipline. The two dimensions of craft and discipline are not logically incompatible:

Journalism is a research practice in so far as it originates truth claims of significance to publics about the state of the world in some particularity. It is also a craft, a profession, an aesthetic practice, a communication practice and so on, and is mostly produced and received in an industrialised and commercialised context. It is not alone in combining those attributes: the law, health sciences, education and history, not to mention the visual arts, architecture and music, readily spring to mind as comparable. (Nash, 2013, p. 130)

It stands uncontested that journalism that is a mere communication or popularisation, however accurate, valuable and stimulating, of original research that is produced elsewhere cannot itself be considered research. Similarly, journalism that is what might be called everyday, journal-of-record professional practice that originates credible truth claims about some contemporary detail of the state of the world (this category would include most reputable short-form news reporting) cannot be considered research on its own (Park, 2006, p. 229), although it may well produce reliable information (or 
conversely a silence) that becomes an object within a larger research exercise in journalism or another discipline such as sociology or history (Park, 2006, p. 232; Trouillot, 1995, p. 26). The professional practice vs research distinction applies to many areas of knowledge application as exampled above and it is a complex issue, but for our purposes here we will acknowledge that only a small proportion of professional practice in any of these disciplines would merit consideration as original research for academic purposes. We will also set aside debates about form and content: innovations in forms of journalistic communication (as distinct from the empirical content of the communication, insofar as they can be distinguished) would still need to demonstrate 'the use of existing knowledge in a new and creative way so as to generate new concepts, methodologies and understandings' in order to be considered research (ARC, 2008).

The types of journalism that are most likely to qualify as research will be investigative and/or long form (Bacon, 1999, 2006, 2011, 2012). Some scholars suggest that investigative journalism is fundamentally different from news journalism in its approach to truth and objectivity (eg. Williams, 1978; Ettema \& Glasser, 1985), but investigative journalism is often produced and reported in iterative form in a portfolio that may include shorter news items and 'performative' elements (Ettema \& Glasser, 1985, p. 188, referencing Fishman, 1980, p. 95ff). The 1970s Watergate scandal is an iconic example of this iterative modality of investigative journalism (Bernstein \& Woodward, 1974), and as long as an instance of research practice can be justified methodologically, its specific modality should not be proscribed. Indeed, the author argues elsewhere that the art and politics of journalism are very much in transition (Nash, 2015, forthcoming).

I want to cut through to the coalface of graduate students and their supervisors faced with the submission requirement of an exegesis or 'critical commentary' to accompany their journalism and confirm its status as research. Hopefully a constructive exploration of this challenge will elucidate some arguments in the larger discussion. The formulation of the precise requirements for such degrees varies with the institution. At my own university candidates for the degree of Doctor of Philosophy (Journalism) must

submit for assessment a major piece of original journalistic research together with a written critical commentary of not more than 100,000 words on the programme of research which meets the requirements of 


\section{INVESTIGATIVE JOURNALISM TRENDS}

the examiners. The research component should be no less than 50,000 words or equivalent and the critical commentary no less than 25,000 words .... [The exegesis or] critical commentary should demonstrate how the professional/creative component contributes to scholarly knowledge in the field. It should address contextual, methodological and/or theoretical issues related to the themes or issues explored in the journalism project. It should demonstrate that the candidate has acquired the ability to research and contribute to journalism studies, and should be between 25,000-35,000 words. (Monash University, 2014)

Dictionary definitions of 'exegesis' include 'critical explanation or interpretation of a text, especially of scripture' (Oxford), 'exposition, explanation; especially: an explanation or critical interpretation of a text' (MerriamWebster), 'critical explanation or analysis, especially of a text' (American Heritage), and 'an explanation that helps you to understand a piece of writing, especially one from the Bible' (Macmillan). The link with religious texts is particularly prominent in the more fulsome Wikipedia definition:

Exegesis (from the Greek 'to lead out') involves an extensive and critical interpretation of any text, especially of a holy scripture, such as of the Old and New Testaments of the Bible, the Talmud, the Midrash, the Qur'an, etc. Persons skilled in the science of exegesis become known as exegetes. The word exegesis means 'to draw the meaning' out of a given text. Some contrast exegesis with eisegesis, which means to read one's own interpretation into a given text. In general, exegesis presumes an attempt to view the text objectively, while eisegesis implies more subjectivity.

Wikipedia (http://en.wikipedia.org/wiki/Exegesis )

For the purposes of this discussion, the term exegesis can be interpreted as the critical interpretation or analysis of a piece of journalism with respect to whether and how it meets the definition of original academic research. The exegesis involves the subsequent or parallel examination of a primary text in another text and genre, here the examination of a journalistic text in a scholarly text. While journalism is necessarily directed towards an identifiable public, the exegesis is directed toward scholars in the relevant field, and therefore it requires a different mode of presentation and analysis from the original, and a critical distance from the primary authorial voice. It requires 
disinterested evaluation, and the ability to situate an analysis of a text within a nominated disciplinary and theoretical framework much as one scholar might apply to another scholar's work in reviewing an article for journal publication. It is a defence or justification of intellectual rigour in a piece of journalism in much the same way that any doctoral candidate would mount a defence of their thesis viva voce.

As such, I suggest the exegesis has three core elements - the literature review, the exposition of the research methodology, and the evaluation of the research outcomes. Together with an introduction that explains its interest value, originality and significance, and a conclusion that confirms those claims on the basis of the research outcomes, the three core elements of the exegesis envelope and locate the journalistic component as the most appropriate disciplinary instrument to produce a logically coherent, rigorous and cogent contribution to knowledge, in exactly the same way that a literature review and research question in chemistry or medical science could generate a laboratory experiment or surgical procedure that would answer the question definitively. Put another way, there should be a seamless logic linking the methodology to the relevant literature and research question such that it is defensible that the journalistic exercise is able to answer the question rigorously and convincingly and thereby make an original contribution to knowledge.

These three elements of the exegesis are, of course, each present in a traditional scholarly thesis, and it is their presence in both traditional and non-traditional research dissertations that identifies both approaches as equally scholarly in making their original contribution to knowledge, and merely different in their disciplinary modality. It should also be clear that the core elements of the exegesis may be present in the journalistic component of the thesis, and may therefore, from a strictly logical point of view, not require separate exposition in another text. Indeed, it is arguable (and this author supports the argument) that such reflexivity, either implicit or expressed in a mode compatible with the artistic and linguistic integrity of the journalism, is an essential requirement of all journalism that claims to make a significant contribution to knowledge. The same applies to any discipline, and is the basis for its continuing development as such (Weinberg, 2002). However, the requirement for degree candidates of a distinct exegesis in traditional scholarly mode as a component of a thesis is valuable for several reasons: firstly, it requires and empowers journalists to participate in scholarly discussion of 
the subject matter on an equal footing with experts from other disciplines; secondly, it makes the point that intellectual argument can be expressed in various artistic and linguistic modalities appropriate to the forum and audience; and thirdly, skilled scholarly and journalistic research practitioners should be able to adjust their mode of communication and defend their practice to a range of audiences.

\section{The literature review}

The starting point for the exegesis is the literature review. It must locate the proposed journalistic research with respect to the existing research literature (both disciplinary and journalistic) on the topic and its contextual disciplinary fields. The literature review explains and justifies the research question by identifying the sources of evidence, perspectives and approaches under discussion in the relevant research literature, and it explores the significance of the scholarly and journalistic debates for the issue at hand. It should be precise about the opportunity and gap in knowledge that needs to be filled, and the disciplinary perspective(s) that might be appropriate. It is that literature, gap and perspective that generates the research question for the journalistic research exercise. For journalists it may be helpful to think of the answer to the research question as the equivalent to the answer to the journalistic question of 'what's the story?' The literature review produces the research question, which then generates and justifies a research methodology, which explains how the research is to be carried out in order to answer the question.

Journalistic research is necessarily interdisciplinary, as indeed are all of the humanities and social sciences broadly, and particularly the closely cognate disciplines of history, geography, sociology and politics. Journalism/ history/ geography, etc. are always about a specific field of human activity eg economics, electoral politics, war, culture, education, sport, etc and those fields have their own dynamic structures and characteristic processes which the journalist/ historian/geographer has to understand and be immersively familiar with in order to conduct serious research.

Hence we have economic history, economic journalism, economic geography; military history, war/peace journalism, military geography; sports history, sports journalism, sports geography, etc. In each of these disciplinary fields the historian/geographer/journalist has to bring their own specific 
disciplinary capabilities and accountabilities to bear (as a heteronomous participant in the field, to use Bourdieu's conceptualisation) at the same time as they appreciate the specific (autonomous) characteristics of the field, be it sport, politics, economics, etc. (Bourdieu \& Wacquant, 1992). The interests and perspectives of the outsider and the insider, as it were, are not identical, which means that the engagement between the two perspectives can range from confluent to conflicted. However, the engagement and potential contest cannot be avoided, because any field has to be understood in terms that can only be appreciated by outsiders through engagement and deep familiarity with its structures and processes (Bourdieu \& Wacquant, 1992; Weinberg, 2002; Pollner, 1991). It is only through understanding the structure and processes of a field that arguably causal relationships can be identified, explored and authoritatively established or contested.

Phillips has alleged that journalists, almost by definition, have a 'lack of expertise in substantive fields of knowledge' (Phillips, 1977, p. 70), which may indeed be an accurate observation when referring to general news reporters, and in which case the resultant journalism on its own can't claim academic quality. However, it is not necessarily the case for all journalists, particularly those who have career specialisations in particular fields, eg parliamentary politics, military conflict, business. Similarly James Carey has argued that journalism is often very poor at articulating the 'why' of a story, frequently reducing it to personalised motives of the protagonists (Carey, 1997). I suggest that this would often be due to a lack of acknowledgement or understanding of the deeper structures and processes of a field and their relevance to the events or activities in the story. Because journalism, like history, is almost infinitely broad in its empirical range, it requires a conceptual framework specific to the field of empirical focus, and that can only be supplied from the relevant field and associated discipline(s). Ipso facto journalism that seeks recognition as an academic research practice, like history, is necessarily interdisciplinary, but in turn that status imposes a responsibility on journalists who want to claim academic recognition for their research to explain and justify its interdisciplinary quality. Journalism, like history, interacts with field-associated disciplines to explore the issue of causality in answering a research question. The nub of the issue is: what does journalism bring to this interaction in terms of singular, rigorous and reflexive research methodology? 


\section{Methodology}

The exposition of the methodology is the second core element of the exegesis. It must explain how the methods and practices deployed in the research are rigorous and appropriate to produce the information that will answer the research question. As argued above, that methodology will involve an interaction between the methodologies appropriate to the substantive empirical field (such as sport, politics, economics, etc) and the journalism methodology. There is no single or simple template setting out a checklist for the discussion of journalistic methodology, just as there is none in other disciplines. Methodological principles and approaches derive from paradigms and practices, which are themselves hotly contested and continually evolving in cycles of long and short duration (Messer-Davidow et al., 1993). Issues can arise in all aspects of research and reporting practice, and in choosing the aspect to focus on in the methodology discussion, it is important to focus on the aspect(s) that go to the integrity of the research and which are most likely to be contested by critics of the ensuing analysis. For example, there is little merit in discussing the interpretation of a set of selected documents if critics allege a failure to access the most important documents relevant to the research; or again, there's not much point in discussing the narrative structure of a report and how it depicts causation in a process if key elements or events in the process have arguably been ignored or suppressed; or again, if the social and geographic location of journalistic production and intended audience is problematic with respect to the research object, that would need to be considered and justified in the methodology.

Journalistic research methods are typically variations on the standard qualitative research methods of the humanities and social sciences, viz. document or artefact discovery and analysis, witness testimony, direct observation, interviewing, and the like. Increasingly, the use of digital data generation and analysis by journalists opens up quantitative methods and methodologies for adaptation and deployment. This commonality means that the interaction between the cognate disciplinary methodology and the journalism takes place around a compatible, even shared set of methods, for example in data analysis, oral history/interviewing, archival research/document analysis, artefact identification and retrieval, the spatio-temporal aspects of direct observation, ideological and strategic pre-dispositions of witnesses and documents, and so forth. The issue is one of methodological compatibility, and if this is present, then the exegesis may be straightforward and non-controversial. 
As with any discipline, there will be specific and identifiable characteristics to the ways in which methods are used and justified theoretically, and this is where lies the potential for dispute about journalism as a disciplinary research practice: does it have theory and methodology, as distinct from a set of unreflexive methods and craft practices? Or put another way, why is journalism the best way to acquire and analyse the appropriate information? What does journalism bring to the research that the cognate discipline lacks?

Given the widespread antipathy to the recognition of journalism as a research discipline, one possible way to approach this issue is to identify the characteristics that critics argue prevent journalism from being an acceptable research practice, and explore whether those alleged weaknesses are in fact indicators of what are the singular characteristics, even strengths, of journalism as a discipline. These alleged weaknesses can be summarised as follows:

- The empirical: a crudely positivist conception of the empirical that separates 'facts' from 'values' and eschews methodological questions

- The temporal: a temporal restriction to narrowly contemporary events and processes that privileges an intuitive 'news sense' and militates against considered reflection and reasoned analysis

- The political: an intrinsic and necessary engagement with the exercise of power in the terms of observation or discovery and representation of events and processes that must corrupt the detachment required for scholarly analysis

These three issues are obviously interlaced and overlapping. They comprise a set of meta-theoretical challenges that will not necessarily need to be addressed comprehensively or in great detail in every exegesis. The level of engagement with them will depend on the characteristics of the research question, and how the journalistic practices intersect with methodologies of the cognate discipline.

\section{The empirical}

In many ways this is the easiest of the three objections to dispose of. The exposition should address with appropriate degrees of emphasis the characteristics of the likely empirical evidence and how it is to be identified and discovered/produced. So, what 'facts' or evidence (statements, objects, activities, events and/or processes) are to be discovered, observed or produced, and how is their validity as evidence to be ascertained and verified? 
Who and/or what sources are to be accessed to produce these facts? Why were they selected and others neglected? What is the significance of these sources? And what are their partisan or vested interests and position within the field being researched?

With respect to any fact or source, there is the possibility that it could pre-exist the journalistic exercise, eg as a document or artefact waiting to be discovered, identified or recognised; or it could be produced expressly for the purposes of the journalistic exercise, for example as a press conference or photo opportunity; or it could be produced as a direct outcome of the journalistic exercise, for example an answer in response to a question. In so far as it has a material existence as an object (artefact, recording, image, etc), its production, discovery and contextualisation will have spatio-temporal characteristics (the when and where of its production and existence) which Tuchman described as a 'web of facticity' located in space and time (Tuchman, 1978). A web cast in specific times and spaces will catch certain events and information, but miss those present at other times and places, and so it will necessarily produce silences and absences among the facts.

A commitment to the concept of 'facts' and the possibility that they can be truthfully (and latterly 'objectively') represented in discourse has been intrinsic to the definition of journalism since its European inception in the 16th century and subsequent development (Schudson, 1978, 2001; Schudson and Anderson, 2009; Ward, 2004). Some scholarly critics allege that this commitment translates to a crude positivism allied with an intuitive so-called 'news sense' potentially riddled with emotional and ideological biases, and with no rigorous methodology underpinning the choice of events and witnesses, nor theoretical framework to explain causation. In passing it is worth noting that such critics are often unclear about the methodological reasoning they themselves have used in the selection of their journalism case studies to make this argument, and as noted above it is specious to have an undifferentiated sample set that confuses quotidian professional practice with reflexive research practice. Even the sociological studies that Zelizer identifies as memorable and foundational (Zelizer, 2009, p. 35) take daily news production in large urban corporations as exemplary samples of journalism for analysis (Tuchman, 1978; Gans, 1979; Fishman, 1980). Among these studies it is Tuchman who directly addresses the question of journalism as a form of knowledge production, and before her Phillips $(1976,1977)$, who used a similar sample set of large-scale newsroom 
production to argue for a dichotomy between journalism and social science.

I am discussing that debate in detail elsewhere (Nash, 2015, forthcoming), and agree with Tuchman that journalism is a 'theoretic' activity because at the stage of research 'facts' for journalists are 'pertinent information gathered by professionally validated methods specifying the relationship between what is known and how it is known' (Tuchman, 1978, p. 82) and at the stage of reporting 'news stories engage in theorising by juxtaposing facts gleaned from sources. Juxtaposition is a form of categorising, since it encourages the understanding that these facts have something to do with one another. It both claims and creates a theoretic relationship between and among the phenomena presented as facts' (Tuchman, 1978, p. 204).

To argue successfully that an activity is 'theoretic' does not of course mean that it is not disputable, nor that the theory being used is necessarily adequate to the task of analysis. However, it does mean that the debate about adequacy can take place within the parameters of methodology, rather then be dismissed as non- or pre-methodological. For example, Tuchman argues that journalism, because of its verification procedures in the production of facticity, necessarily supports the status quo in any social structure. In this position she is extending the arguments put by Schutz (1964), Goffman (1974), Garfinkel (1967) and Berger and Luckmann (1967) about reflexivity in the social sciences generally, again locating journalism among the academic disciplines in its knowledge production methodologies.

Tuchman's approach to journalism as knowledge production is enormously energising because it puts paid to the dismissal of its methodology as 'primitive empiricism'. The debates she discussed have only expanded and developed since the 1970s, and beyond the North American social sciences there are related debates across the humanities, in history, anthropology, geography and beyond, and in all their diversity and disagreements they provide fertile ground for journalists wanting to probe and develop the methodological dimensions of their own research practice (for example, see Benson and Neveu (2005), Bacon and Nash (2012) and Chubb and Nash (2012) for the application of Bourdieusian sociology to journalism studies). This commonality in methodological concerns further enhances the necessary interdisciplinarity in empirical issues discussed above.

A second significant contribution that Tuchman made was to link the production of 'facticity' to the spatio-temporal organisation of journalists' 


\section{INVESTIGATIVE JOURNALISM TRENDS}

research and reporting activity (Tuchman, 1978:, p. 15-63). Stuart Adam concurred: 'journalism is marked equally by its relation to the here and now' (Adam, 1994, p. 13). Facticity is produced by journalists in specific spatial contexts in a constantly unfolding present interpreting the significance of recently past events and anticipating likely future ramifications in order to organise their activities to produce verifiable truth claims about these material events and objects. Facticity is anchored for subsequent verification purposes by the spatio-temporal referents of the procedures used by journalists to identify, research and report phenomena as verifiable facts. This points to the spatio-temporality of journalistic methods as a crucial dimension for analysis and theorisation as methodology, and is eminently available for exploration in an exegesis.

Tuchman and Adam used the conceptual categories of time and space without attempting to analyse or theorise them. Gell (2001) has offered an anthropological overview and account of how time is conceptualised, and he addresses precisely the two requirements of conceptualising the present as the context for practice as well as using time as an event locator. He follows Gale (1968) in categorising the phenomenological time of past, present and future as 'A-series' time, and the chronometric time of event location according to a linear grid as 'B-series' time. Gell accepts the argument that the two conceptualisations or series of time are mutually incompatible. We do not have to address that paradox here, but simply note that journalists constantly operate in both A- and B-series time, as indeed does humanity generally, and that there is ample capacity for exploration of the temporality of journalistic practice in the scholarly literature on time.

A similar situation pertains to the question of space. For example, the geographer David Harvey advanced a multi-dimensional conceptualisation of spatiality in 1973, re-confirmed it in 2006, and in the intervening years produced a large body of work exploring the ramifications of this approach that is particularly relevant to journalism (Harvey, 1973, 2006). Absolute space comprises the material world of physically manifest objects and their characteristics which can be ascertained empirically by the senses and whose specificities can be named and verified, for example, the address and physical characteristics of a building. It is the space that contains objects, events and processes that journalists attest to as real, factual and able to be observed and located at a place in a recognised measurement grid or map. Relative space 
comprises space in relation to time; in other words, space that is subject to the impact of movement, whether it be of objects or energy flows. It incorporates change and processes, for example a developing news story, a meeting in progress, a session of parliament or the stock market, a game of sport, the transmission of audio-visual data through an electronic communications network. Change and process are essential components of news as a concept and professional practice for journalists, who constantly plan for their own movements in space and time in reaction to or anticipation of events. Change and process are also essential dimensions of 'news sense', which is concerned with the anticipated significance of an event or process.

Harvey's third dimension of spatiality is relational space, which is space as it is produced by relationships between social or physical entities including energy sources. It includes the relations between buyers and sellers that produce economic markets; human feelings and thoughts that produce emotional and imaginative environments; energy differentials that produce the fields of force in geological, chemical, physical, biological environments, and so on. Relevant contemporary examples in journalism would include the relationships that produced the Global Financial Crisis in economic markets, and climatic relationships promoting global warming.

Relative space incorporates absolute space, and relational space incorporates both absolute and relative space, but Harvey argues that they should be viewed not hierarchically but dialectically, and that all three dimensions are manifest in any given spatial phenomenon (Harvey, 2006, p. 142). Journalists need to operate in all three dimensions simultaneously: absolute space to reference the physical facts that provide evidence for their reports, relative space to understand the processes that are producing the facts in absolute space and therefore be able to anticipate or explain them, and relational space to understand the forces at work that drive the processes that produce the factual outcomes. It is in relational space that news values reside, because it is in the ramifications for real human beings and their social relations that the significance of facts and processes reside. In this journalism is no different from the other humanities and social sciences.

Harvey makes the essential point that values and social relations are not directly observable, but are induced from their imputed effects as observable phenomena and evidence in absolute and relative space (Harvey, 2006, p. 142). In Harvey's terms, this means that journalists, like other scholars of 
social relations, are constantly presenting 'facts' or verifiable, measureable observations of phenomena in absolute and relative space in order to present analyses of abstract relational space, which is where news values apply. This argument is related to that of Tuchman and others about the verifiability of 'social facts'. It also explains why 'news' is not a category of objects that can be precisely described but a continuous process of contemporaneous interpretation of shifts in abstract relationships based on the interpretation of observable phenomena. But of course it also means that journalistic truth claims will necessarily be subject to political contestation in their production and interpretation, just as Flyvbjerg following Foucault and Bourdieu argued is the case in all the non-natural sciences and humanities (Flyvbjerg, 2001).

The work and approaches of Tuchman, Gell and Harvey briefly cited above are examples of work done in recent decades in cognate disciplines that is highly relevant to journalistic research practices. The critical exploration of this and related work on spatio-temporality, in my view, offers a fertile challenge for scholarly journalists to undertake, and it is relevant to the question of the exegesis for two basic reasons: firstly, it puts their research work on a methodological par with other disciplines, and secondly, it engages with the disciplinary singularity and specificity of journalism as it contributes to the development of new knowledge.

\section{The temporal}

There are two issues for journalism regarding temporality that I would like to address here, apart from the two indicated above, viz. the relationship with spatiality of concern to Harvey, and the two mutually incompatible modes of conceptualising time discussed by Gell. The first issue of concern for a journalism exegesis is that because journalism by definition is concerned with the contemporary, there is an issue of whether there is insufficient time for adequate consideration of all relevant factors and evidence at play in any given situation. Lack of adequate time for empirical research and consideration could then lead to faulty or partial analyses.

In the context of journalism produced for a masters or doctoral thesis, there are several responses to this concern. Firstly, journalism is an iterative process and journalistic analyses can continually be updated as more evidence and factors are considered and analysed. Over the period that a thesis is being prepared (minimum of two years for a fulltime masters degree and three years 
for a doctorate), there is ample time for successive iterations of any ambiguous component of the research. The same considerations would apply here as in other disciplines, for example oral history interviews, field observations in anthropology, sociology and geography, and so on.

Secondly, there are situations in practice-based disciplines such as medical surgery, classroom teaching, psychiatry, nursing and other health sciences, military science, legal casework and courtroom processes, where practitioner-researchers have no choice but to make analyses and decisions in very short timeframes, sometimes seconds. Each discipline has to support research practice in such situations with protocols and procedures that minimise the risks of faulty data collection, analysis and responses (Tuchman, 1972; Hughes, 1964, pp. 94-98), and in the case of practice claiming to be research (as distinct from quotidian professionalism) those protocols and procedures need to be rigorously reviewed and justified. But that is precisely the role of the exegesis, and besides, it would be a deeply paralysing argument (even if sustainable) to assert that valid forms of knowledge cannot be produced in the present and are produced only at some significant period after the events or conditions to which they apply.

Thirdly, the journalistic principle of separating fact from interpretation, while it might be logically flawed and susceptible to the arguments considered above about reflexivity, does also make provision for conflict and contestation in the interpretation of evidence. Tropes of 'fairness' and 'balance' have a long history (Ward, 2004), and while supremely amenable to subversion and manipulation, they do allow for critical contestation, which is precisely the basis of scholarly enquiry. In the context of long form journalism for a thesis, as distinct from the hothouse of live-to-air news and current affairs programming, there is ample opportunity for the range of considered opinion to be justified and defended, and again it is precisely the role of the exegesis to hold such consideration to rigorous account.

The second and more substantial issue with respect to temporality is the central role of 'news sense' in guiding journalists' decision-making (eg., Phillips, 1977; Tuchman, 1978).

The concept of 'news sense' describes an instinct or intuition that is imprecise yet acute, and which journalists depend on to identify and 'follow' a story. In the sociological literature on journalism it is a ubiquitous concept that is notorious for its imprecision, and journalists are notorious for their 
inability to explain or define what 'news' is. But as Baker (1981) pointed out in a little-known but elegant piece of research, journalists have a very finely tuned appreciation of its precise qualities in any given newsroom context, and are able to construct subtle status hierarchies amongst their peers with respect to the congruence of their news sense with that of the 'terminal gatekeepers' exercising editorial authority in their workplace.

Bourdieu's concept of habitus as a 'capacity for structured improvisation' (Calhoun et al., 1993, p. 4) is highly relevant to an understanding and dissection of the role and attributes of 'news sense'. Bourdieu himself has expounded upon the concept extensively (particularly in Bourdieu, 1977, 1990), and it has been widely and critically engaged with in the sociology and cultural studies literature, and to a lesser though growing extent in journalism studies (Benson \& Neveu, 2005; Nash 2011, 2015 forthcoming; Chubb \& Nash, 2012; Bacon \& Nash, 2012; Roberts \& Nash, 2009). There are two pertinent points to make in the context of journalism. Firstly, Bourdieu explicitly advances the concept of habitus to support a theory of practice in knowledge production that is opposed to both 'positivistic materialism' and 'intellectual idealism' (Bourdieu \& Wacquant, 1992, p. 121). In other words, it is well-placed to transcend Phillips' polarity between an instinctual 'nose for news' and 'primitive empiricism' (Phillips, 1977, p. 71). Secondly, Bourdieu explicitly applies the concept of habitus to research practice in science (Bourdieu, 2004, p. 70), and so its exegetical exploration with respect to journalism can be assessed on a par with that in other academic disciplines.

Bourdieu is not the only theorist of knowledge production to engage with the issues of intuition, reflexivity and relativism (see Plessner et al., 2008 for a recent overview; Weinberg, 2002; Flyvbjerg, 2001) and we do not have to engage with those debates here. It is sufficient to note that there is an ample literature exploring the issues of temporality and intuition with respect to knowledge production, which firstly provides a fertile field for reference to journalism practice, and secondly locates that consideration in the context of research practice in both the natural and social sciences.

\section{The political}

It is platitudinous to state that attempts by powerful interests to inhibit or influence journalism are intrinsic to the process of news and information production and dissemination. There is ample evidence that journalism is highly susceptible to such inhibition and influence: one could almost say that the 
scholarly and professional literature describing and analysing the subversion of truthfulness in and by journalism is almost co-terminous with journalism itself. Hall et al. (1978) and Ericson et al (1989) might disagree on the structural power relations between journalists and their sources, but they concur that a major role of journalism is to validate the authority of powerful people and institutions. Some critics go so far as to say that journalism is too important to be left to journalists (eg., Hartley, 2008, p. 39), and there is a strong element of truth in that insight. But no more so than to say that health is too important to be left to doctors, justice to lawyers, education to teachers and indeed knowledge-seeking to academics. The recognition and critique of power exercised in knowledge production across the disciplines and professions is no less cogent for the natural and social sciences than for journalism (Flyvbjerg, 2001), though it is perhaps a recognition of the importance of journalism to human affairs that its pillorying is often more strident.

The fundamental importance of journalism lies in the introduction of the truth object or fact into contemporaneous socio-political discourse, or alternatively the production of silence about truth objects and facts (Bacon \& Nash, 2012). The historian Michel-Rolph Trouillot identified four stages where power is exercised in the production of history and its attendant silences, in his case the history of Afro-American slavery:

Silences enter the process of historical production at four crucial moments: the moment of fact creation (the making of sources); the moment of fact assembly (the making of archives); the moment of fact retrieval (the making of narratives); and the moment of retrospective significance (the making of history in the final instance). (Trouillot, 1995, p. 26 [emphasis in original])

Only a slight substitution of (underlined) terms makes clear the parallels with the journalistic production process:

Silences or information enter the process of historieat news production at four crucial moments: the moment of fact creation (the making of sources); the moment of fact assembly (the making of archives, notes or collections of information); the moment of fact retrieval (the making of narratives or stories); and the moment of retrospeetive contemporary significance (the making of history news in the final contemporary instance). 
In journalism these four stages may sometimes be compacted into a contemporaneous set of processes, for example in 'live' news and current affairs coverage. However, for analytical purposes, they remain a fruitful way to conceptualise the process of journalistic production, for example in an exegesis. The first three stages are integral stages in the research production process, while the fourth offers the chance to discuss the contribution to and reception of knowledge at both the public and scholarly levels. The last is particularly important for journalism, because its intrinsic accountability to publics for the purposes of furthering democratic processes of governance embeds the political factor in all aspects of journalistic research and communication practice. This is not something to be apologised for, but to be recognised and analysed.

Each scholar will have his/her own preferred framework for conceptualising and exploring the relationship of power to knowledge production. For this author considering the practice of journalism, Tuchman (1978), Hall et al. (1978), Ericson et al. (1989), Schlesinger (1990), Benson \& Neveu (2005), Bourdieu (various), Harvey (various) and Lefebvre $(1990,2008)$ are key nodes of reference across a range of theoretical perspectives. The salient point for the purposes of an exegesis is that the available literature to discuss the exercise of power in journalism practice is firstly huge and diverse, and secondly able to locate journalism methodologically on a par with academic research practices.

\section{The evaluation}

The evaluation section of the exegesis is relatively straightforward: it examines the execution of the journalistic methodology and its empirical results for their adequacy in answering the research question. It should be clear from the discussion above that there is as broad a range of meta-theoretical literature applicable to journalism as a research practice as there is to any disciplinary endeavour in the humanities and social sciences, or according to some perspectives, in all sciences - natural and social. Because of the fundamentally interdisciplinary character of journalism, that execution will always be made at the interface with the cognate discipline appropriate to the empirical field of study. There will be both confluence and conflict at that interface, and the evaluation should be assertive in exploring both aspects.

It should also be clear that the empirical, temporal and political axes, around which much criticism has been made of journalism, are as much potential strengths for its practice as they are potential weaknesses; and indeed, 
when sitting at the table of knowledge with other disciplines, they may well characterise the distinctive contributions that journalism makes. Each of the three axes are extensively explored in the meta-theoretical literature on knowledge production and human praxis, and this literature supplies a deep well for the journalist exegete to draw from in theorising their research practice.

In conclusion, I should say that for this author, the mix of interdisciplinarity, focus on the 'here and now', the imperative for empirical rigour and an acute sensitivity to the political forces and accountabilities at play in journalism is a heady one. It is a mix that has delivered invigorating intellectual and professional rewards over many years spent combining work as a journalist and an academic. The process of engagement with this mix has been very much a developmental and exploratory one, with its full share of diversions and blind alleys and much use of rear vision to clarify and understand the principles and forces underpinning earlier practice. It is a process that promises great rewards for any researcher setting out to plan and produce an exegesis for their own journalism.

\section{References}

Adam, G. S. (1994). Notes towards a definition of journalism: Understanding an old craft as an art form. St Petersburg, FL: Poynter Papers No. 2, The Poynter Institute for Media Studies.

Adam, G.S. and Clark, P. (2005). Journalism: The democratic craft. New York: Oxford University Press.

Australian Research Council (2008). ERA Indicator Descriptors. Retrieved on August 29, 2013, from www.arc.gov.au/pdf/ERA_Indicator_Descriptors.pdf

Bacon, W. (1999). What is a journalist in a university? Media International Australia, 92, pp. 79-90.

Bacon, W. (2006). Journalism as research. Australian Journalism Review, 28(2), p. $147-157$.

Bacon, W. (2011). Investigative journalism in the academy - possibilities for storytelling across time and space. Pacific Journalism Review, 17(1), pp. 45-66.

Bacon, W. (2012). An innovative direction in academic journalism. Pacific Journalism Review, 18(2), pp. 153-165.

Bacon, W. and Nash, C. (2012). Playing the media game. Journalism Studies, 13(2) pp. 243-258.

Baker, I. (1980). The gatekeeper chain. In Edgar, P. (Ed.), The news in focus (pp. 136-158). Melbourne: Macmillan.

Benson, R. and Neveu, E. (2005). Bourdieu and the journalistic field, Cambridge: Polity Press. 
Berger, P. and Luckmann, T., (1967). The social construction of reality. Garden City, NY: Doubleday-Anchor.

Bernstein, C. and Woodward, R., (1974). All the president's men, New York: Simon and Schuster.

Bourdieu, P. (1977). Outline of a theory of practice. Cambridge: Cambridge University Press.

Bourdieu, P. (1990) The logic of practice Cambridge: Polity Press

Bourdieu, P. and Wacquant, L. (1992). An invitation to reflexive sociology. Cambridge: Polity Press.

Calhoun, C., LiPuma, E. and Postone, M, eds. (1993). Bourdieu: Critical perspectives. Chicago: University of Chicago Press,

Carey, J. (1986). 'The dark continent of American journalism'. Published in Munson, E. and Warren, C. (1997), James Carey: A critical reader. Minneapolis: University of Minnesota Press,

Carey, J. (1996). Where journalism education went wrong. Paper presented to the 1996 Siegenthaler Conference on Journalism Education, the First Amendment Imperative, and the Changing Media Marketplace, at Middle Tennessee State University.

Chubb, P. and Nash, C. (2012). The politics of reporting climate change at the Australian Broadcasting Commission. Media International Australia. No 144, pp. 37-48

Ericson, R. Baranek, P. and Chan, J. (1989). Negotiating control: A study of news sources. Milton Keynes: Open University Press.

Ettema, J. and Glasser, T. (1985). On the epistemology of investigative journalism, Communication, Vol 8, pp 183-206

Ettema, J. and Glasser, T. (1998). Custodians of conscience: Investigative journalism and public virtue. New York: Columbia University Press

Fishman, M. (1980). Manufacturing the news. Austin: University of Texas Press

Flyvbjerg, B. (2001). Making social science matter: Why social inquiry fails and how it can succeed again. Cambridge: Cambridge University Press

Gale, R. (ed.) (1968). The philosophy of time: A collection of essays. London: Palgrave-Macmillan

Gans, H., (1979). Deciding what's news. New York: Pantheon

Garfinkel, H., (1967). Studies in ethnomethodology. Englewood Cliffs, NJ: PrenticeHall

Gell, A. (1992). The anthropology of time. New York: BERG.

Goffman, E. (1974). Frame analysis. Philadelphia: University of Pennsylvania Press

Hall, S., Critcher, C., Jeffersen, T., Clarke, J., and Roberts, B., (1978). Policing the crisis: Mugging, the state, and law and order. London: Macmillan.

Hartley, J. (2008). Journalism as a human right: The cultural approach to journalism. In Loffelholz, M. and Weaver, D. (2008), Global journalism research: Theories, methods, findings, future. Oxford: Blackwell.

Harvey, D. (1973). Social justice and the city London: Edward Arnold

Harvey, D. (2006). Spaces of global capitalism: Towards a theory of uneven development. London: Verso. c.4 'Space as a keyword'. 
Hughes, E. (1964). Men and their work. Glencoe, Ill.: Free Press

Lefebvre, H. (1991). The social production of space. Oxford: Blackwell.

Lefebvre, H. (2002). Critique of everyday life, Volume 2: Foundations for a sociology of the everyday. London: Verso.

Merrill, J., Gade, P. and Blevens, F. (2001). Twilight of press freedom: The rise of people's journalism. London: Lawrence Erlbaum Associates, publishers

Monash University (2014). Doctor of Philosophy (Journalism) www.monash.edu.au/ pubs/handbooks/courses/4103.html Retrieved on August 29, 2013.

Nash , C., (2011). Fields of Conflict: Journalism and the construction of Sydney as a global city 1983 - 2008. Unpublished PhD manuscript.

Nash, C. (2013). Journalism as a research discipline. Pacific Journalism Review, 19(2) pp. 123-135.

Nash, C. (2015). What is journalism? The art and politics of a transition. London: Palgrave Macmillan.

Park, R. (2006). News as a form of knowledge. In Adam, G.S. and Clark, P. Journalism: The democratic craft. New York: Oxford University Press.

Phillips, E.B., (1976). What is news? Novelty without change. Journal of Communication 26(4), pp. 87-92.

Phillips, E.B., (1977). Approaches to objectivity: journalistic vs social science perspectives. In Hirsch, P.M., Miller, P.V. and Kline, F.G. (eds) Strategies for communication research. Beverley Hills: Sage.

Plessner, H., Betsch, C., and Betsch, T., (2008). Intuition in judgment and decisionmaking. London: Lawrence Erlbaum Associates.

Pollner, M., (1991). Left of ethnomethodology: The rise and decline of radical reflexivity. American Sociological Review, 56(3), pp. 370-380.

Protess, M. et al. (1991). The journalism of outrage: Investigative reporting and agenda building in America. New York: Guildford Press.

Roberts, J. and Nash, C. (2009). 'Reporting controversy in health policy: A content and field analysis'. Pacific Journalism Review, 15(2), pp. 35-53.

Schlesinger, P., (1990) 'Rethinking the sociology of journalism: Source strategies and the limits of media-centrism'. In Ferguson, M., (ed.), Public communication: The new imperatives: Future directions in media research. London: Sage, pp. 61-83.

Schudson, M. (1978). Discovering the news: A social history of American newspapers. New York: Basic Books

Schudson, M. (2001). The objectivity norm in American journalism. Journalism: Theory, Practice, Criticism, 2(2), pp. 149-170.

Schudson M. and Anderson, (2009). Objectivity, professionalism and truth-seeking in journalism. In Wahl-Jorgensen, K. and Hanitzsch, T. (Eds.), The Handbook of Journalism Studies. London: Routledge.

Schutz, A., (1964). Collected papers, volume II: Studies in social theory. The Hague: M. Nijhoff.

Sylvan, D. Messer-Davidow, E. Shumway, D (1993). Knowledges: Historical and critical studies in disciplinarity. Charlottesville: University Press of Virginia. 


\section{INVESTIGATIVE JOURNALISM TRENDS}

Tuchman, G. (1978). Making news: A study in the construction of reality. New York: Free Press.

Turner, G. (2011). The ERA and journalism research. Australian Journalism Review, $33(1)$, pp. $5-7$.

Turner, G. (2012). What's become of cultural studies? Los Angeles: Sage.

Trouillot, M.-R. (1995). Silencing the past: Power and the production of history. Boston: Beacon Press.

Ward, S. (2004). The invention of journalism ethics. Montreal: McGill-Queens University press.

Weinberg, D. (2002). Qualitative research methods. Malden: Blackwell.

Williams, P., (1978). Investigative reporting and editing. Englewood Cliffs, New Jersey: Prentice-Hall.

Zelizer, B., (2004). Taking journalism seriously: News and the academy. Thousand Oaks: Sage.

Zelizer, B. (2009). Journalism and the academy. In Wahl-Jorgensen, K. and Hanitzsch, T. (eds.), The Handbook of Journalism Studies. London: Routledge.

Dr Chris Nash is foundation Professor of Journalism at Monash University in Melbourne, Australia, and is on the editorial board of Pacific Journalism Review. His book, What is Journalism? The art and politics of a transition, will be published by Palgrave Macmillan in 2015. chris.nash@monash.edu 